\title{
LIVER AND KIDNEY GLUCOSE-6-PHOSPHATASE ACTIVITY IN CHILDREN WITH NORMAL AND DISEASED ORGANS ${ }^{1}$
}

\author{
BY RUTH C. HARRIS AND CARMEN OLMO \\ (From the Department of Pediatrics, Columbia University College of Physicians and Surgeons, \\ and the Babies Hospital, New York City, N. Y.)
}

(Submitted for publication March 12, 1954; accepted May 14, 1954)

Through the work of the Coris and their coworkers $(1-6)$ over the past twenty years, the structure of glycogen has been clarified and the enzymes necessary for its degradation to glucose have been determined. These enzymes are 1) phosphorylase, 2) amylo-1, 6-glucosidase, 3) phosphoglucomutase, and 4) glucose-6-phosphatase.

In 1949, Marjorie Swanson $(7 ; 8)$ isolated purified glucose-6-phosphatase from rat liver and found it specific for conversion of glucose-6-phosphate to glucose. She devised a method for the assay of this enzyme which has been used primarily in rats.

Utilizing this technique, a preliminary report of levels of liver glucose-6-phosphatase in 14 patients from 1 month to 10 years of age was made in 1952 (9). A more complete report is herein presented including a total of 37 assays of liver glucose-6phosphatase on 34 patients and 6 assays of kidney enzyme activity.

\section{METHOD}

The liver tissue samples obtained at biopsy varied from $0.043 \mathrm{Gm}$. to $0.507 \mathrm{Gm}$. in weight. They were immediately chilled in an iced container after surgical removal. Homogenization and determination of the enzyme activity was usually carried out during the next 2 to 3 hours, while in a few cases the tissue was frozen for later estimation. Those samples obtained at postmortem examination were treated in an identical manner and were obtained at intervals ranging from $1 \frac{1}{2}$ to 19 hours after death. Weights of postmortem tissues used for homogenization varied from 0.2 to $0.8 \mathrm{Gm}$. Specimens were obtained at random from either lobe of the liver. Kidney cortex was obtained at autopsy for renal studies. In four instances, including the case of glycogen heart disease, estimates of heart muscle glucose-6-phosphatase activity showed zero levels.

The liver was ground in a glass homogenizer and diluted approximately 10 fold with 1 per cent glucose solution. Of this, a $0.1 \mathrm{ml}$. aliquot was incubated with 0.1 $\mathrm{ml}$. of 0.1 molar glucose- 6 -phosphate and $0.2 \mathrm{ml}$. of $0.1 \mathrm{M}$

1 This work was supported by a grant from Mead Johnson and Company. citrate buffer at pH 6.5 at $37^{\circ}$ C. for 30 minutes. Simultaneously, an equal sample of buffered liver homogenate was incubated without substrate. The reaction was terminated by immersion of the tubes in cracked ice and by the addition of $1.0 \mathrm{ml}$. of ice-cold 10 per cent trichloracetic acid. After standing for $\mathbf{5}$ minutes, a final dilution to $2.5 \mathrm{ml}$. was made. The mixture was centrifuged for 5 minutes and duplicate $1.0 \mathrm{ml}$. aliquots were used for inorganic phosphorus determination by a modification of the method of Fiske and SubbaRow (10). The difference in $\mathbf{P}$ content of the homogenate incubated with substrate from that incubated alone represented the enzyme activity of the liver. A blank containing all reagents except the liver homogenate revealed no free inorganic phosphorus. The final results of enzyme activity were expressed as mg. P released from substrate per gram of wet liver tissue. Where large amounts of tissue were available, values were expressed in terms of dry weight.

In these cases, since the glycogen occupies so much space, a liver overloaded with glycogen might contain less enzyme activity per gram of weight than a normal liver. To correct this possible error in the comparison of normal livers and livers with excess glycogen content, the nitrogen content of the liver was obtained and the final enzyme activity was expressed as milligram phosphorus per gram of tissue nitrogen.

Repeated estimations of enzyme activity in frozen specimens showed slight loss of activity over several months.

\section{RESULTS}

Liver biopsy specimens were obtained from three infants at operation for pyloric stenosis (Table I). These infants were moderately malnourished, had a moderate increase in deposition of fat vacuoles within the liver cells, but were believed to have normal liver function. Necropsy specimens of liver were obtained from six other patients ranging in age from 40 hours to $5 \frac{1}{2}$ years. These patients had diseases which did not reveal histological changes in the liver. Specimens were obtained between 3 and 7 hours after death, except in the case of J. C. when the sample was obtained 19 hours after death. The range of values for enzyme activity varied from 3.9 to $5.8 \mathrm{mg}$. $\mathrm{P}$ per $\mathrm{Gm}$. of wet tissue with an average of $4.9 \mathrm{mg}$. $\mathrm{P}$, or from 165 
TABLE I

Glucose-6-phosphatase activity in normal livers

\begin{tabular}{|c|c|c|c|c|c|c|c|}
\hline \multirow[b]{2}{*}{ Patient } & \multirow[b]{2}{*}{ Age } & \multirow[b]{2}{*}{ Diagnosis } & \multicolumn{4}{|c|}{ Enzyme activity } & \multirow[b]{2}{*}{ Microscopic liver findings } \\
\hline & & & $\frac{\text { mg. P } \mathrm{P}}{\substack{\text { Gm. wet } \\
\text { liver }}}$ & $\frac{\text { mg. P }}{\substack{\text { Gm. dry } \\
\text { liver }}}$ & $\frac{\text { mg.total N\& }}{\substack{\text { Gm. wet } \\
\text { liver }}}$ & $\frac{\mathrm{mg} \cdot \mathbf{P}}{\mathbf{G m} \cdot \mathbf{N}}$ & \\
\hline J.F.* & 6 wks. & Pyloric & 5.0 & 18.3 & 20.2 & 246. & Glycogen-moderate \\
\hline K. C.* & 4 wks. & $\begin{array}{l}\text { Pyloric } \\
\text { stenosis }\end{array}$ & 5.4 & 22.9 & 18.1 & 299. & Fat vacuoles-abundant \\
\hline N. K.* & 5 wks. & $\begin{array}{l}\text { Pyloric } \\
\text { stenosis }\end{array}$ & 5.6 & 20.1 & & & Fat vacuoles-several \\
\hline B. A.† & 40 hrs. & $\begin{array}{l}\text { Premature; } \\
\text { Pneumonia }\end{array}$ & 3.9 & 20.5 & 23.5 & 165. & $\begin{array}{l}\text { Extra-medullary } \\
\text { hematopoiesis }\end{array}$ \\
\hline J. C.† & 10 days & $\begin{array}{l}\text { Duodenal } \\
\text { atresia ; } \\
\text { Kernicterus }\end{array}$ & 5.8 & 24.8 & 25.4 & 229. & $\begin{array}{l}\text { Hemosiderosis } \\
\text { Hematopoiesis-mild }\end{array}$ \\
\hline $\begin{array}{l}\text { J. D'A. } \dagger \\
\text { D. W. } \dagger\end{array}$ & $\begin{array}{l}34 \text { days } \\
5 \frac{1}{2} \text { yrs. }\end{array}$ & $\begin{array}{l}\text { Thyroid cysts } \\
\text { Gargoylism; } \\
\text { Endocarditis }\end{array}$ & $\begin{array}{l}4.9 \\
4.4\end{array}$ & $\begin{array}{l}16.6 \\
19.5\end{array}$ & $\begin{array}{l}24.3 \\
26.0\end{array}$ & $\begin{array}{l}199 . \\
168 .\end{array}$ & Fat vacuoles-present \\
\hline J. W.† & 5 mos. & $\begin{array}{l}\text { Bronchiolitis; } \\
\text { Celiac crisis }\end{array}$ & 5.0 & 23.2 & 30.3 & 166. & \\
\hline M. F.† & 5 mos. & $\begin{array}{l}\text { Amyotonia } \\
\text { congenita }\end{array}$ & 4.5 & 18.6 & 19.0 & 236. & \\
\hline
\end{tabular}

* Biopsy.

† Autopsy.

$\$ \mathrm{P}=$ phosphorus released from substrate, glucose-6-phosphate, by unit measure (Gm.) of liver.

$\mathrm{N}=$ nitrogen content of liver.

to $299 \mathrm{mg}$. $\mathrm{P}$ per $\mathrm{Gm}$. of liver nitrogen with an average of $214 \mathrm{mg}$. $P$ (Standard Deviation \pm 45 mg.) (Table V). The difference between values obtained at biopsy and necropsy is not significant. Greater variation between results is noted when differences in water content and nitrogen content of the tissues were calculated. This is clearly demonstrated in the case of M. F. whose phosphatase activity of $4.47 \mathrm{mg}$. $P$ per $\mathrm{Gm}$. of wet tissue is the third lowest figure in the range of normal values, while the enzyme activity of $236 \mathrm{mg}$. $\mathrm{P}$ as expressed per $\mathrm{Gm}$. of tissue $\mathrm{N}$ is the third highest value of the group (Table I). Therefore, for standardization of method wherever possible values were expressed in terms of nitrogen content rather than wet weight of tissue.

Glucose-6-phosphatase activity was determined in various diseases and conditions involving the liver (Table II) to evaluate whether enzyme activity is depressed only in specific abnormalities of glycogen storage or whether non-specific insult to the liver will also lower the enzyme activity. In five instances, invasion of the liver by tumor tissue or abnormal cells caused significant reduction of glucose-6-phosphatase activity. In three of seven cases of probable hepatitis or pericholangitis, the specific enzyme activity was more than three standard deviations below the normal, while of the remaining four cases only one was within one standard deviation of the normal. All cases of edema of the liver, passive congestion, biliary and Laënnec's cirrhosis, fatty liver and acute and chronic atrophy were accompanied by reduction of glucose-6-phosphatase activity commensurate with the degree of damage to the liver as observed histologically.

Liver glucose-6-phosphatase activity was studied in two patients with clinical and histological evidence of glycogen storage disease of the liver (von Gierke's disease) (Table III). Liver tissue from one of these patients (W. M.) was examined by Dr. Gerty Cori, who reported that the glycogen was of normal structure (11). Our estimation of liver glucose-6-phosphatase activity in this patient was four and one-half standard deviations below the mean. This patient also had an associated glycogen-containing liver tumor which had less enzyme activity per gram of tissue than did the more normal areas of the liver.

T. A. had a typical clinical picture of glycogen storage disease with hypoglycemia, ketosis and lactic acid acidosis and a liver which extended into the pelvis. The liver at biopsy contained large amounts of glycogen which did not disappear after 
24 hours; its enzyme activity was only slightly greater than that of W. M. Death occurred at age 3 years 7 months. Autopsy was not permitted.
Postmortem studies of glycogen content and enzyme activity of tissue were performed in a 2month-old infant (D. B.) who was observed from

TABLE II

Liver glucose-6-phosphatase activity in miscellaneous diseases of the liver

\begin{tabular}{|c|c|c|c|c|c|c|c|}
\hline \multirow[b]{2}{*}{ Patient } & \multirow[b]{2}{*}{ Age } & \multirow[b]{2}{*}{ Diagnosis } & \multicolumn{4}{|c|}{ Enzyme activity } & \multirow[b]{2}{*}{ Liver pathology } \\
\hline & & & $\frac{\substack{\text { mg. } P t \\
\text { Gm. wet } \\
\text { liver }}}{\text { live }}$ & $\frac{\text { mg. } P}{\substack{\text { Gm.dery } \\
\text { liver }}}$ & $\frac{\text { mg.total No }}{\substack{\text { Gm. wet } \\
\text { tissue }}}$ & $\frac{\mathrm{mg} \cdot \mathbf{P}}{\mathrm{Gm} \cdot \mathbf{N}}$ & \\
\hline M. C.† & 14 mos. & $\begin{array}{l}\text { Neuroblastoma } \\
\text { a) normal liver } \\
\text { b) tumor liver }\end{array}$ & $\begin{array}{l}3.4 \\
0.6\end{array}$ & $\begin{array}{r}14.8 \\
3.3\end{array}$ & $\begin{array}{l}23.0 \\
21.8\end{array}$ & $\begin{array}{r}147 . \\
26 .\end{array}$ & Edema of liver \\
\hline S. B.† & $4 \frac{1}{2}$ yrs. & $\begin{array}{l}\text { Nephrosis; } \\
\text { Chronic glomerulo- } \\
\text { nephritis }\end{array}$ & 2.7 & & & 117. & Edema of liver \\
\hline J.P.† & 19 mos. & $\begin{array}{l}\text { Letterer-Siwe } \\
\text { disease }\end{array}$ & 2.4 & 10.4 & 28.4 & 84. & \multirow{2}{*}{$\begin{array}{l}\text { Reticulo-endotheliosis; } \\
\text { Giant cells; Kupffer cells } \\
\text { increased } \\
\text { Reticulo-endotheliosis }\end{array}$} \\
\hline M. W. $t$ & 2 yrs. & $\begin{array}{l}\text { Reticulo- } \\
\text { endotheliosis }\end{array}$ & 0.8 & 3.3 & 29.0 & 26. & \\
\hline J.R.t & $1 \frac{1}{2}$ yrs. & Leukemia & 2.5 & 11.1 & 34.6 & 103. & \multirow{3}{*}{$\begin{array}{l}\text { Leukemic infiltration; } \\
\text { Multinucleate liver cells } \\
\text { Some portal fibrous tis- } \\
\text { sue and bile duct prolif- } \\
\text { eration } \\
\text { Hepatitis; } \\
\text { Liver healing } \\
\text { Cirrhosis }\end{array}$} \\
\hline G. H.* & 9 yrs. & $\begin{array}{l}\text { Rhabdomyo- } \\
\text { sarcoma }\end{array}$ & 3.7 & 14.9 & 23.4 & 158. & \\
\hline $\begin{array}{l}\text { S. D. }{ }_{\dagger}^{*} \\
\text { A. S. } \dagger\end{array}$ & $\begin{array}{l}3 \text { mos. } \\
10 \text { mos. } \\
30 \text { days }\end{array}$ & $\begin{array}{l}\text { Hepatitis } \\
\text { Pneumonia (?) } \\
\text { Cirrhosis; } \\
\text { Kidnev abscesses }\end{array}$ & $\begin{array}{l}1.6 \\
3.2 \\
1.7\end{array}$ & $\begin{array}{r}6.4 \\
12.3 \\
8.6\end{array}$ & $\begin{array}{l}20.9 \\
33.0 \\
20.0\end{array}$ & $\begin{array}{l}76 . \\
97 . \\
85 .\end{array}$ & \\
\hline R. T.† & 14 mos. & $\begin{array}{l}\text { Infectious mono- } \\
\text { nucleosis }\end{array}$ & 0.9 & 3.1 & 17.9 & 43. & \multirow{3}{*}{$\begin{array}{l}\text { Acute hepatitis; Sub- } \\
\text { acute yellow atrophy; } \\
\text { Fatty } \\
\text { Subacute yellow atrophy } \\
\text { with localized regenera- } \\
\text { tion } \\
\text { Mild pericholangitis }\end{array}$} \\
\hline T.S.* & $3 \frac{1}{2}$ yrs. & $\begin{array}{l}\text { Subacute yellow } \\
\text { atrophy }\end{array}$ & 1.0 & & & & \\
\hline C. S.† & 5 wks. & $\begin{array}{l}\text { Chronic intestinal } \\
\text { obstruction }\end{array}$ & 6.4 & 29.8 & 27.3 & 234. & \\
\hline C. So* & $2 \frac{1}{2}$ yrs. & Cirrhosis & 3.6 & 14.3 & 30.0 & 146. & \multirow{5}{*}{$\begin{array}{l}\text { Pericholangitis; } \\
\text { Periportal cirrhosis } \\
\text { Multinucleated liver } \\
\text { cells; Cirrhosis } \\
\text { Pericholangitis; } \\
\text { Biliary cirrhosis } \\
\text { Biliary cirrhosis focal; } \\
\text { Cysts of intrahepatic bile } \\
\text { ducts } \\
\text { Laennec's cirrhosis } \\
\text { Fatty; Binucleate liver } \\
\text { cells }\end{array}$} \\
\hline E. B.* & 4 mos. & Hepatitis & 0.08 & & & & \\
\hline R. J.* & $2 \frac{1}{\mathrm{mos}}$ & Bile duct atresia & 3.7 & & 25.6 & 146. & \\
\hline G. D. $†$ & $13 \frac{1}{y r s}$. & $\begin{array}{l}\text { Fibrocystic } \\
\text { disease of } \\
\text { pancreas }\end{array}$ & 2.1 & 10.7 & 22.1 & 96. & \\
\hline $\begin{array}{l}\text { R. M. } \dagger \\
\text { C. W. } \dagger\end{array}$ & $\begin{array}{l}3 \text { yrs. } \\
3 \text { yrs. }\end{array}$ & $\begin{array}{l}\text { Lead poison (?) } \\
\text { Low gamma } \\
\text { globulin; } \\
\text { Intestinal }\end{array}$ & $\begin{array}{l}0.2 \\
2.4\end{array}$ & $\begin{array}{l}7.2 \\
9.6\end{array}$ & $\begin{array}{l}25.8 \\
22.8\end{array}$ & 104. & \\
\hline L. A. $†$ & $4 \frac{1}{2}$ mos. & $\begin{array}{l}\text { obstruction } \\
\text { Congestion of liver; } \\
\text { Nephro-calcinosis }\end{array}$ & 2.7 & 10.4 & 27.6 & 97. & Fatty \\
\hline A. L.* & $4 \frac{1}{2}$ yrs. & $\begin{array}{l}\text { Congestion of liver; } \\
\text { Tumor (?) }\end{array}$ & 3.4 & 13.6 & 28.5 & 119. & \multirow{4}{*}{$\begin{array}{l}\text { Acute passive congestion; } \\
\text { Central atrophy } \\
\text { Some portal areas large, } \\
\text { some small; } \\
\text { Anomalous bile ducts } \\
\text { Atrophy of liver }\end{array}$} \\
\hline Ja. Co.* & 12 mos. & $\begin{array}{l}\text { Cysts of liver; } \\
\text { Hypoglycemia }\end{array}$ & 3.6 & 14.6 & 24.6 & 146. & \\
\hline G. T. $†$ & $1 \frac{1}{2}$ yrs. & $\begin{array}{l}\text { Spastic diplegia; } \\
\text { Pneumonia; } \\
\text { Cachexia }\end{array}$ & 1.9 & 7.9 & 31.3 & 60.9 & \\
\hline G. M.* & 4 mos. & Hepatitis & 2.7 & 10.5 & 29.9 & 90. & \\
\hline
\end{tabular}

* Biopsy.

t Autopsy.

$\exists \mathbf{P}=$ phosphorus released from substrate, glucose-6-phosphate, by unit measure (Gm.) of liver. $\mathrm{N}=$ nitrogen content of liver. 
TABLE III

Liver glucose-6-phosphatase activity in glycogen storage disease

\begin{tabular}{|c|c|c|c|c|c|c|}
\hline \multirow[b]{2}{*}{ Patient } & \multirow[b]{2}{*}{ Age } & \multirow[b]{2}{*}{ Diagnosis } & \multicolumn{4}{|c|}{ Enzyme activity } \\
\hline & & & $\frac{\text { mg. P }}{\substack{\text { Gm. wet } \\
\text { liver }}}$ & 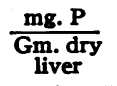 & $\frac{\text { mg. total N\& }}{\text { Gm. wet tissue }}$ & $\frac{\mathrm{mg} \cdot \mathbf{P}}{\mathrm{Gm} \cdot \mathbf{N}}$ \\
\hline W. M.† & 10 yrs. & a) Liver storage & $\begin{array}{l}0.23 \\
0.16\end{array}$ & $\begin{array}{l}0.80 \\
0.48\end{array}$ & 23.39 & 9.7 \\
\hline $\begin{array}{l}\text { T. A. }{ }^{*} \\
\text { D. B.† }\end{array}$ & $\begin{array}{l}5 \frac{1}{2} \text { mos. } \\
2 \text { mos. }\end{array}$ & $\begin{array}{l}\text { Liver storage } \\
\text { Heart storage }\end{array}$ & $\begin{array}{l}0.46 \\
6.86\end{array}$ & $\begin{array}{r}1.35 \\
22.46\end{array}$ & 20.07 & 342.0 \\
\hline
\end{tabular}

* Biopsy.

$\dagger$ Autopsy.

P = phosphorus released from substrate, glucose-6-phosphate, by unit measure (Gm.) of liver.

$\mathrm{N}=$ nitrogen content of liver.

birth with suspected glycogen storage disease of the heart. Clinically there was cardiomegaly with progressive $T$ wave changes in the electrocardiogram, a large tongue and a liver which measured $5 \mathrm{~cm}$. below the costal margin, fasting blood sugar levels of $60,80,89,84$ and normal glucose, fructose and galactose tolerance tests. Large deposits of glycogen were present in heart and skeletal muscle. Dr. Cori studied the glycogen in these tissues and reported its structure to be made up of glucose radicals in normal chain length. Using a slightly different method (12), Dr. Cori reported that the liver glucose-6-phosphatase was normal (11). Our estimations of glucose-6-phosphatase activity of the liver measured $342 \mathrm{Gm}$. P released from substrate per gram of liver nitrogen. This is 2.9 standard deviations above our normal average for liver enzyme activity.
Postmortem analysis of kidney cortex for enzyme activity (Table IV) showed much lower values in the two normal kidneys (av. $=119 \mathrm{mg}$. $P$ per $\mathrm{Gm} . \mathrm{N}$ ) than was obtained in the livers. Patients with renal disease or infiltration had enzyme activity much lower than the normal, while the kidney cortex of one patient (W. M.) with glycogen storage disease of the liver had only five per cent of the expected normal activity. Enzyme activity of the kidney cortex of D. B., the patient with glycogen storage disease of the heart, was not tested by us but was determined by Dr. Cori (11).

\section{COMMENT}

Within the limits of the small samples available, these studies show the relative constancy of glucose-6-phosphatase activity of tissue of normal

TABLE IV

Glucose-6-phosphatase activity of kidney cortex in normal and pathological conditions (postmortem specimens)

\begin{tabular}{|c|c|c|c|c|c|c|}
\hline \multirow[b]{2}{*}{ Patient } & \multirow[b]{2}{*}{ Age } & \multirow[b]{2}{*}{ Diagnosis } & \multicolumn{4}{|c|}{ Enzyme activity } \\
\hline & & & $\frac{\text { mg. P* }}{\text { Gm.wet }}$ & $\frac{\text { mg. } P}{\substack{\text { Gm.dry } \\
\text { kidney }}}$ & $\frac{\text { mg. total Nt }}{\text { Gm. wet tissue }}$ & $\frac{\mathrm{mg} . \mathrm{P}}{\mathrm{Gm} \cdot \mathrm{N}}$ \\
\hline M. F. & 5 mos. & $\begin{array}{l}\text { Pneumonia; } \\
\text { Amyotonia } \\
\text { congenita }\end{array}$ & 2.6 & 14.8 & 22.2 & 115. \\
\hline $\begin{array}{l}\text { J. W. } \\
\text { A. S. }\end{array}$ & $\begin{array}{l}5 \text { mos. } \\
30 \text { days }\end{array}$ & $\begin{array}{l}\text { Celiac crisis } \\
\text { Liver cirrhosis ; } \\
\text { Kidney abscesses }\end{array}$ & $\begin{array}{l}2.3 \\
1.7\end{array}$ & $\begin{array}{r}15.1 \\
8.6\end{array}$ & $\begin{array}{l}18.7 \\
20.0\end{array}$ & $\begin{aligned} 122 . \\
85 .\end{aligned}$ \\
\hline L. A. & $4 \frac{1}{2}$ mos. & $\begin{array}{l}\text { Nephro calcinosis; } \\
\text { Liver congestion }\end{array}$ & 1.3 & 6.7 & 21.0 & 61. \\
\hline M. W. & 2 yrs. & $\begin{array}{l}\text { Reticulo- } \\
\text { endotheliosis }\end{array}$ & 0.6 & 3.0 & 26.1 & 22. \\
\hline W. M. & 10 yrs. & $\begin{array}{l}\text { Glycogen liver } \\
\text { disease }\end{array}$ & 0.18 & 0.8 & & \\
\hline
\end{tabular}

* $P=$ phosphorus released from substrate, glucose-6-phosphate, by unit measure (Gm.) of kidney.

$+\mathrm{N}=$ nitrogen content of kidney. 
TABLE V

Liver glucose-6-phosphatase activity

\begin{tabular}{|c|c|c|c|c|c|c|c|c|}
\hline & \multicolumn{2}{|c|}{ 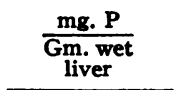 } & \multicolumn{2}{|c|}{$\frac{\text { mg. } P}{\text { Gm. dry }}$} & \multicolumn{2}{|c|}{$\frac{\text { mg. } N}{\substack{\text { Gm. wet } \\
\text { liver }}}$} & \multicolumn{2}{|c|}{$\frac{\text { mg. } \mathbf{P}}{\mathbf{G m} \cdot \mathbf{N}}$} \\
\hline & M.** & S.D.† & M. & S.D. & M. & S.D. & $\overline{\mathbf{M}}$ & S.D. \\
\hline Normal livers & $\begin{array}{l}4.9 \\
(9) \ddagger\end{array}$ & 0.6 & $\begin{array}{c}21.0 \\
(9)\end{array}$ & 3.0 & $\begin{array}{c}23.0 \\
(8)\end{array}$ & 4.0 & $\begin{array}{c}214.0 \\
(8)\end{array}$ & 45. \\
\hline $\begin{array}{l}\text { All liver disease } \\
\text { except glycogen } \\
\text { storage of liver }\end{array}$ & $\begin{array}{l}2.5 \\
(23)\end{array}$ & 1.4 & $\begin{array}{l}11.0 \\
(20)\end{array}$ & 5.0 & $\begin{array}{l}26.1 \\
(21)\end{array}$ & 4.0 & $\begin{array}{c}104.0 \\
(21)\end{array}$ & 49. \\
\hline $\begin{array}{l}\text { Liver in } 2 \text { cases } \\
\text { glycogen storage }\end{array}$ & $\begin{array}{l}0.4 \\
(2)\end{array}$ & & $\begin{array}{l}1.1 \\
(2)\end{array}$ & & $\begin{array}{c}23.0 \\
(1)\end{array}$ & & $\stackrel{9.7}{(1)}$ & \\
\hline $\begin{array}{l}\text { Liver in } 1 \text { case } \\
\text { glycogen storage } \\
\text { of heart }\end{array}$ & 6.9 & & 22.5 & & 20.1 & & 342.0 & \\
\hline
\end{tabular}

* Mean.

† Standard deviation.

$\ddagger()=$ Number of examinations.

infants and children and indicate the degree of suppression of this enzyme's activity in various diseases. The only circumstances in which its activity seems to approach zero are in those cases of abnormal storage of glycogen in liver and kidney. Autolysis studies in these instances have also shown very slow breakdown of glycogen structure.

Of interest is the one case of glycogen storage disease of the heart in which liver (and kidney) glucose-6-phosphatase activity was greater than normal. There also appeared to be greater storage of liver glycogen than was expected, and the structure of the glycogen was found on analysis to be normal. This infant also had relatively high fasting blood sugar levels for his age. One wonders whether these findings usually accompany a defect in muscle glycogen breakdown or whether this is unique.

\section{SUMMARY}

Studies of glucose-6-phosphatase activity of liver and kidney tissue, using the method of Swanson, were performed on biopsy and autopsy material obtained from patients varying in age from 40 hours to $13 \frac{1}{2}$ years. The normal range of activity was determined and compared with the lower values obtained in various diseases affecting liver and kidney. Enzyme activity in two cases of glycogen storage disease of the liver was almost absent, while the liver enzyme activity in one case of glycogen storage disease of the heart was abnormally high.

Addendum: Liver glucose-6-phosphatase activity in a biopsy specimen from a three-month-old infant with ideopathic hypoglycemia, not due to von Gierke's disease or pancreatic adenoma, was 6.2 mg. $P$ per $\mathrm{Gm}$. of wet tissue, or $252 \mathrm{mg}$. $P$ per Gm. N.

\section{REFERENCES}

1. Cori, G. T., Colowick, S. P., and Cori, C. F., The enzymatic conversion of glucose-1-phosphoric ester to 6-ester in tissue extracts. J. Biol. Chem., 1938, 124, 543.

2. Cori, G. T., Cori, C. F., and Schmidt, G., The rôle of glucose-1-phosphate in the formation of blood sugar and synthesis of glycogen in the liver. J. Biol. Chem., 1939, 129, 629.

3. Illingworth, B., and Cori, G. T., Structure of glycogens and amylopectins. III. Normal and abnormal human glycogen. J. Biol. Chem., 1952, 199, 653.

4. Swanson, M. A., and Cori, C. F., Studies on the structure of polysaccharides. III. Relation of structure to activation of phosphorylases. J. Biol. Chem., 1948, 172, 815.

5. Cori, G. T., and Larner, J., Action of amylo-1, 6-glucosidase and phosphorylase on glycogen and amylopectin. J. Biol. Chem., 1951, 188, 17.

6. Cori, G. T., Structure of glycogen and enzyme patterns in glycogen storage disease. Science, 1952, 116, 519. 
7. Swanson, M. A., Specificity of liver glucose-6-phosphatase. Federation Proc., 1949, 8, 258.

8. Swanson, M. A., Phosphatases of liver. I. Glucose-6 phosphatase. J. Biol. Chem., 1950, 184, 647.

9. Harris, R. C., Preliminary studies of liver glucose-6phosphatase in von Gierke's disease. Am. J. Dis. Child., 1952, 84, 627.

10. Fiske, C. H., and SubbaRow, Y., The colorimetric de- termination of phosphorus. J. Biol. Chem., 1925, 66, 375.

11. Cori, G. T., Glycogen structure and enzyme deficiencies in glycogen storage disease. Harvey Soc. Lectures, 48, p. 145, March 19, 1953, N. Y., Academic Press, 1954.

12. Cori, G. T., and Cori, C. F., Glucose-6-phosphatase of the liver in glycogen storage disease. J. Biol. Chem., 1952, 199, 661. 